\title{
PENILAIAN SIKAP PESERTA DIDIK DALAM PEMBELAJARAN KIMIA MELALUI TEKNIK SELF ASSESSMENT DAN PEER ASSESSMENT
}

\author{
Hairida \\ FKIP Universitas Tanjungpura, Jalan Prof. Dr. H. Hadari Nawawi, Pontianak \\ E-mail: hairida@fkip.untan.ac.id
}

DOI: 10.26418/jpmipa.v9i2.25832

\begin{abstract}
Student participation in assessment is essential so that students could understand what to do in learning. The purpose of this research is to find out the use of self assesment and peer assessment technique in attitude assessment on chemistry learning is effective, and teachers' and students' response to self assessment and peer assessment in chemistry learning. The research method used in this research is qualitative method with descriptive approach. Self assessment sheet and peer assessment sheet in the form of questionnaire and interview as the tool for collecting data. The result concluded that self assessment and peer assessment technique is effective to evaluate 10th grader students' attitudes of SMAN in Pontianak in chemistry subject. Teacher and student response to self assessment and peer assessment shows good criterion, with average score 82.4 and 80.5.

Keywords: attitude assessment, self assessment, peer asessment
\end{abstract}

Pendidikan karakter diperlukan untuk membangun bangsa yang bermartabat. Pengintegrasian pendidikan karakter pada setiap materi pembelajaran sangat penting dilakukan oleh guru saat ini. Pembelajaran yang dilakukan guru sebaiknya tidak hanya menekankan pada selesainya penyampaian materi pelajaran, namun pendidikan karakter secara bertahap sangat perlu dikembangkan pada setiap materi yang disampaikan. Dengan demikian, sistem penilaian yang dilakukan oleh guru juga harus semakin baik dan menyeluruh.

Perubahan standar penilaian dalam kurikulum 2013 seharusnya diikuti dengan perubahan penilaian dalam pembelajaran. Penilaian tidak hanya dapat dilakukan oleh guru, namun peserta didik juga dapat melakukan penilaian terhadap tugastugas yang sudah dilaksanakannya. Selain itu, penilaian tidak hanya dominan penilaian kognitif, melainkan penilaian afektif dan psikomotorik harus mendapatkan perhatian guru dalam proses pembelajaran.

Meskipun telah ditegaskan tentang sistem penilaian yang harus dilakukan guru sehubungan dengan diberlakukannya kurikulum 2013, namun guru belum sepenuhnya melaksanakannya. Hasil studi 
pendahuluan yang dilakukan peneliti (2017) di SMA Pontianak berkaitan dengan penilaian yang dilakukan guru ditemukan: 1) Anggapan dari guru bahwa penilaian yang berkaitan dengan kepribadian atau sikap sangat sulit dilakukan, karena memerlukan waktu yang banyak dan karakteristik siswa yang dinilai sangat variatif, 2) Guru sulit merancang alat penilaian untuk mengukur sikap peserta didik. Hasil pengamatan di kelas menunjukkan bahwa guru membuat tabel penilaian sikap tanpa membuat rubrik penilaian, kemudian melakukan pengamatan, karena jika melihat rubrik memerlukan waktu yang banyak sedangkan peserta yang diamati cukup banyak. Ada juga guru yang membuat rubrik penilaian sikap, tetapi saat penilaian sikap tidak digunakan karena lebih fokus pada penyampaian materi pelajaran. Muslich (2014: 144) menemukan bahwa ada guru memberikan nilai terhadap sikap tanpa melakukan penilaian sikap, hanya berdasarkan nilai ulangan aspek kognitif yang ditambahkan nilai sikap. Penilaian guru masih terbatas pada paper and pencil test, penilaian aspek sikap dan keterampilan masih kurang (Hairida, 2016: 209). Hal ini mengindikasikan bahwa guru mengalami kesulitan dalam melakukan penilaian sikap dalam proses pembelajaran, sehingga nilai sikap yang diberikan guru dengan predikat tertentu bukan berdasarkan hasil pengamatan yang sesuai.

Hasil analisis Kompetensi Dasar untuk Kompetensi Inti sikap sosial dalam mata pelajaran kimia untuk kurikulum 2013, menunjukkan bahwa komponen sikap yang harus dimiliki siswa kelas $\mathrm{X}$, yaitu: rasa ingin tahu, disiplin, jujur, objektif, terbuka, mampu membedakan fakta dan opini, ulet, teliti, bertanggung jawab, kritis, kreatif, inovatif, demokratis, komunikatif dalam kegiatan merancang dan melakukan percobaan serta berdiskusi, kerjasama, santun, toleran, cinta damai dan peduli lingkungan dalam memanfaatkan sumber daya alam. Berarti komponen sikap tersebut penting untuk dikembangkan guru dalam pembelajaran kimia. Hasil ketercapaian Kompetensi Dasar tersebut ditentukan oleh penilaian yang dilakukan guru secara tepat.

Sikap yang ditunjukkan peserta didik dalam pembelajaran dapat menjadi sangat variatif, tergantung dari model atau metode pembelajaran yang digunakan. Semakin bervariasi metode yang digunakan, maka sikap yang akan ditunjukkan peserta didik juga bervariasi, sehingga penilaian sikap yang dibuat guru menjadi bervariasi juga. Keadaan ini yang membuat guru kesulitan dalam merancang penilaian sikap, terutama dalam pembuatan rubrik. Hal tersebut sesuai penelitian Hairida (2017:1) yang menyimpulkan bahwa penyusunan rubrik penilaian menjadi kendala bagi mahasiswa calon guru kimia dalam merancang alternative assessment. Nurmasyitah dan Hudiyatman (2016:58) menyebutkan bahwa guru mengalami kesulitan dalam menyusun rubrik penilaian sikap, terutama pada penentuan indikator, sehingga dalam proses penilaian sikap guru tidak menggunakan angket dan rubrik penilaian.

Tuntutan kurikulum 2013 yang menghendaki pembelajaran dapat mengembangkan karakter siswa tentunya akan sukar terwujud jika tidak ada perubahan cara penilaian yang dilakukan guru. Kinerja siswa yang ditunjukkan dalam pembelajaran 
seharusnya dilakukan penilaian oleh guru, sehingga dapat memberikan motivasi siswa untuk beraktivitas dalam pembelajaran. Sebenarnya ada teknik penilaian yang dapat dilakukan guru jika siswa yang dinilai cukup banyak, sehingga sikap yang dinilai semakin bervariasi, yaitu self assessment dan peer assessment.

Self assessment atau penilaian diri adalah penilaian yang dilakukan peserta didik sendiri terhadap pekerjaannya sedangkan peer assessment atau penilaian rekan adalah penilaian yang dilakukan oleh peserta didik terhadap rekannya atau teman sejawatnya (Alias, Masek, dan Salleh, 2015:309). Peserta didik membuat penilaian tentang prestasi dan proses belajar, dan keputusan tentang tindakan yang harus mereka ambil untuk membuat kemajuan lebih lanjut dalam belajar. Kedua penilaian ini dapat membantu tugas guru dalam penilaian jika peserta didik yang dinilai dalam jumlah yang banyak. Banyak manfaat yang akan diperoleh guru jika menggunakan kedua penilaian ini.

Amo dan Jareno (2011:42) menyebutkan bahwa self assessment bermanfaat untuk: 1) memotivasi diri siswa untuk belajar memberikan penilaian dengan baik, 2) meningkatkan kepercayaan diri siswa, 3) mendapatkan pengalaman baru dalam kegiatan pembelajaran, 4) mendapatkan wawasan dalam melakukan penilaian, 5) meningkatkan berpikir kritis siswa karena ada dorongan untuk mencari dan menemukan sesuatu dengan teliti untuk diberikan catatan atau komentar. Didukung beberapa hasil penelitian menunjukkan bahwa self dan peer assessment berpengaruh positif terhadap aspek koginitif afektif, dan psikomotorik. Penelitian Rochmiyati (2013: 333) ditemukan bahwa peer dan self assessment berdampak positif terhadap peningkatan perolehan nilai rata-rata kelas pada kecakapan kognitif. Selanjutnya penelitian Purmanah, Nuryana, dan Puspitasari (2017:78) ditemukan bahwa penilaian selfassessment dapat menumbuhkan kesadaran siswa tentang makna belajar dengan persentase hasil penerapan penilaian self-assessment pada aspek kognitif sebesar 78,25\% termasuk kedalam kategori kuat, pada aspek afektif sebesar $72,75 \%$ dan aspek psikomotorik sebesar $63 \%$ termasuk juga kedalam kategori kuat. Selanjutnya penelitian Juhanda (2017: 8) ditemukan bahwa peer dan self assessment dapat mengembangkan kemampuan komunikasi lisan dan pemahamn konsep. Banyaknya manfaat dan dukungan hasil penelitian terhadap self dan peer assessment tidak berarti para guru banyak menggunakan self assessment dan peer assessment, karena masih banyak kendala ketika melakukan penilaian tersebut (Grez, et al., 2012:2). Seumumnya siswa menyatakan ragu terhadap kemampuan rekannya dalam melakukan penilaian. Guru belum memiliki model penilaian yang menggunakan teknik self dan peer assessment. Untuk itu, teacher assessment masih diperlukan jika siswa belum terbiasa menggunakan self assessment dan peer assessment. Menurut Chang dan Wu (2012:265) teacher assessment adalah penilaian yang dilakukan oleh guru untuk mengevaluasi hasil pembelajaran dan mengukur aktivitas siswa selama proses pembelajaran. Berdasarkan pemaparan di atas, maka masalah yang dikaji dalam penelitian ini adalah: 1) Apakah teknik self dan peer assessment efektif digunakan 
untuk penilaian sikap siswa kelas $\mathrm{X}$ SMA Pontianak pada mata pelajaran kimia?, 2) Bagaimana respon siswa dan guru terhadap penggunaan teknik self assessment dan peer assessment dalam penilaian sikap siswa?

\section{METODE}

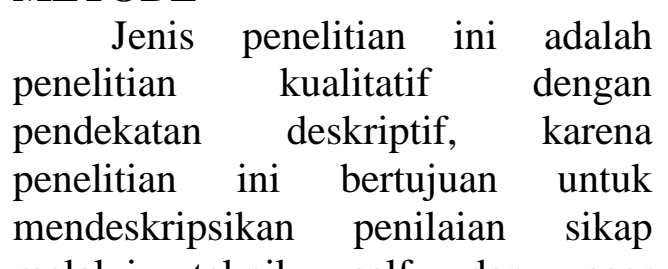
melalui teknik self dan peer assessment dalam mata pelajaran kimia pada peserta didik kelas $\mathrm{X}$ SMA Pontianak dan respon peserta didik dan guru terhadap penggunaan teknik self dan peer assessment. Instrumen yang digunakan untuk pengumpulan data penelitian yaitu kuesioner, wawancara, dan lembar angket respon. Lembar kuesioner self assesment diisi oleh peserta didik sendiri dan peer assessment diisi oleh rekan yang duduk di sebelahnya serta teacher assessment diisi oleh guru.

Lembar self assessment dan peer assessment berupa daftar checklist berisi pernyataan-pernyataan yang berkaitan dengan sikap jujur, teliti, disiplin, percaya diri, dan bertanggung jawab. Lembar teacher's assessmen berupa daftar checklist berisi pernyataan-pernyataan yang berkaitan dengan sikap jujur, teliti, disiplin, percaya diri, dan bertanggung jawab, namun diisi berdasarkan hasil pengamatan guru. Penilaian sikap ini dilakukan dalam pembelajaran kimia materi perkembangan model atom, pembentukan ikatan ion, ikatan kovalen, ikatan kovalen koordinasi, dan ikatan logam. Teacher assessment ini sebagai pengontrol untuk self dan peer assessment.
Selanjutnya wawancara dilakukan pada guru dan peserta didik setelah kegiatan self assessment dan peer assesment. Tujuannya untuk melengkapi data tentang sikap siswa. Agar tercapai tujuan tersebut, maka penelitian terbagi atas tiga tahap, yaitu tahap pendahuluan, pelaksanaan dan tahap analisis data, rinciannya sebagai berikut:

1. Tahap Pendahuluan

Pada kegiatan ini dikaji beberapa literatur berupa buku, jurnal, laporan penelitian, dan sumber-sumber lainnya, misalnya guru, peserta didk, kepala sekolah dan dan wakilnya yang berkaitan dengan variabel penelitian. Hasil kajian tersebut digunakan sebagai dasar dalam perumusan masalah dan tujuan penelitian. Selanjutnya merancang instrumen penelitian. Instrumen yang dirancang dalam penelitian, yaitu self assessment dan peer assessment untuk penilaian sikap yang mengacu dari Kompetensi Dasar materi kimia kelas X SMA dan angket respon untuk peserta didik dan guru. Langkah-langkah merancang instrumen sebagai berikut:

a. Mengkaji teori-teori yang berkaitan dengan sikap sosial,

b. Membuat indikator instrumen,

c. Membuat kisi-kisi instrumen,

d. Membuat instrumen,

e. Memvalidasi instrumen dengan 2 (dua) ahli bahasa dan 2 (dua) ahli evaluasi dalam bidang IPA. Validasi yang dilakukan adalah validasi isi.

Data yang diperoleh dari angket penilaian uji ahli berisi kesesuaian konstruksi, substansi 
dan bahasa pada produk yang dikembangkan. Hasil dari validasi dikategorikan

berdasarkan perolehan rerata skor (Widoyoko, 2012: 111).

Tabel 1. Kategorikan berdasarkan perolehan rerata skor.

\begin{tabular}{|c|c|c|c|c|}
\hline & \multicolumn{2}{|c|}{$\begin{array}{l}\text { Self dan Peer } \\
\text { Assessment }\end{array}$} & \multicolumn{2}{|c|}{ Angket Respon } \\
\hline & $\begin{array}{l}\text { Rerata } \\
\text { Skor }\end{array}$ & Kategori & $\begin{array}{l}\text { Rerata } \\
\text { Skor }\end{array}$ & Kategori \\
\hline Ahli Bahasa & 3,40 & $\begin{array}{l}\text { Sangat } \\
\text { Baik }\end{array}$ & 3,60 & $\begin{array}{l}\text { Sangat } \\
\text { Baik }\end{array}$ \\
\hline $\begin{array}{l}\text { Ahli } \\
\text { Evaluasi }\end{array}$ & 3,38 & $\begin{array}{l}\text { Sangat } \\
\text { Baik }\end{array}$ & 3,63 & $\begin{array}{l}\text { Sangat } \\
\text { Baik }\end{array}$ \\
\hline
\end{tabular}

Selanjutnya dilakukan penentuan subyek penelitian, didasarkan dari hasil diskusi dengan dengan guru mata pelajaran kimia. Diperoleh subyek penelitian, yaitu kelas X SMAN di Pontianak. Secara keseluruhan jumlah subyek yang berpartisipasi dalam penelitian sebanyak 38 orang.

2. Tahap Pelaksanaan

Semua kegiatan yang sudah direncanakan pada tahap pendahuluan, dilaksanakan pada tahap ini. Adapun kegiatan yang dilakukan pada tahap ini adalah:

a. Memberikan penjelasan tentang self dan peer assessmenet, mulai dari tujuan, manfaat, prosedur pelaksanaan, dan kriteria yang digunakan, agar siswa memahami tentang kedua asesmen tersebut serta pengertian kejujuran dalam kehidupan sehari-hari dan penilaian.

b. Membimbing siswa melakukan self dan peer assessement melalui simulasi dalam pembelajaran kimia, sehingga pada saat penelitian siswa sudah terbiasa dalam melakukan self dan peer assessment.

c. Guru melakukan kegiatan pembelajaran, sebelumnya siswa dibagikan lembar pengamatan self assessment dan peer assessment. Siswa menilai dirinya sendiri pada aspek afektif dengan mengisi lembar kuesioner self assessment dan menilai kemampuan rekannya dengan mengisi lembar kuesioner peer assessment. Kegiatan ini dilakukan dalam proses pembelajaran berlangsung.

3. Tahap Analisis Data

Data yang sudah terkumpul pada tahap pelaksanaan selanjutnya dianalisis. Data siswa pada self assessment berbeda dengan data peer assessment dikelompokkan kemudian dilakukan wawancara pada siswa yang bersangkutan. Selanjutnya dilakukan pemberian angket respon siswa terhadap penggunaan self dan peer assessment. Kegiatan 
pengumpulan data diakhiri dengan pemberian angket respon guru terhadap penggunaan self dan peer assessment. Untuk pengolahan angket respon terhadap self dan peer assessment berdasarkan kriteria (Riduwan, 2013:29). Selanjutnya data penelitian diolah untuk disimpulkan

\section{HASIL DAN PEMBAHASAN}

Untuk mengetahui sikap siswa kelas $\mathrm{X}$ dalam pembelajaran kimia, maka digunakan teknik self dan peer assessment. Peserta didik diberi lembar kuesioner yang diisi sendiri oleh peserta didik (self assessment) dan diisi oleh rekan (peer assessment).

1. Penilaian Sikap

a. Penilaian I

Secara keseluruhan rerata skor penilaian sikap peserta didik menggunakan teknik self, peer, dan teacher assessment berturut-turut yaitu 3,27 dengan keriteria sangat baik, dan 3,14 dengan kriteria baik, dan 2,81 dengan kriteria baik. Secara rinci perbedaan hasil dari rerata skor setiap peserta didik dapat dilihat secara jelas pada Gambar 1.

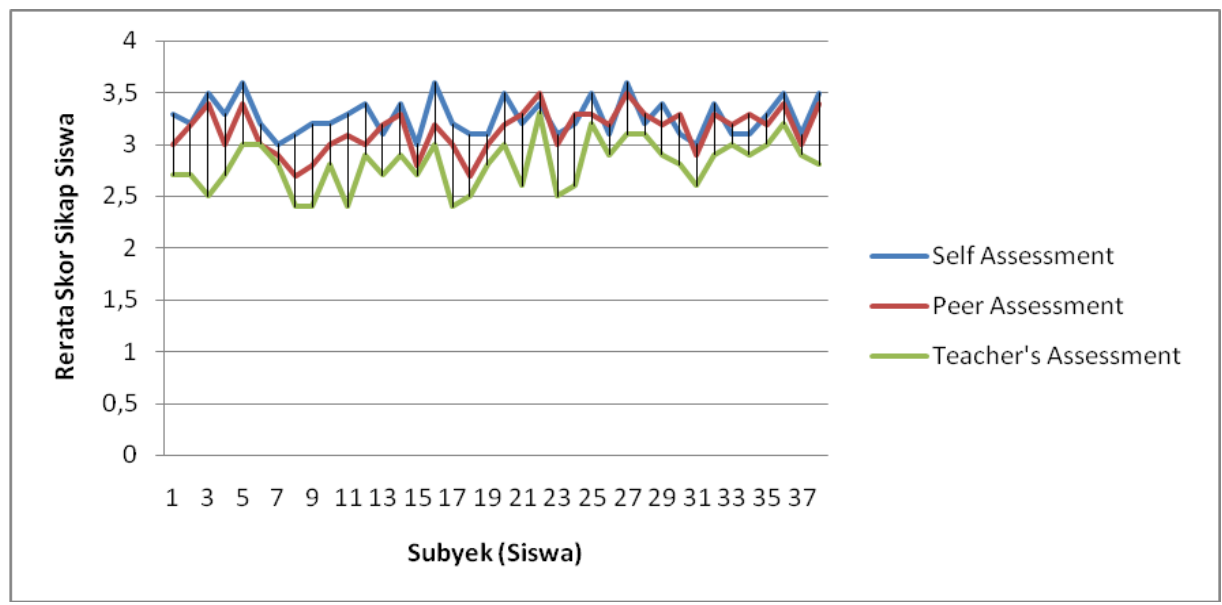

Gambar 1. Rata-rata skor penilaian sikap melalui self, peer, dan teacher assessment pada penilaian pertama.

Berdasarkan data penilaian sikap melalui teknik self assessment dan peer assessment yang dilaksanakan pada pembelajaran kimia menunjukkan, bahwa masih ada perbedaan skor pada self, peer dan teacher assessment. Hal ini menunjukkan bahwa penilaian yang dilakukan peserta didik masih belum obyektif. Hasil penilaian peserta didik lebih tinggi daripada penilaian guru. Hasil wawancara pada siswa diperoleh informasi bahwa ada kekhawatiran peserta didik jika melakukan teknik self assessment secara jujur, dapat mempengaruhi penilaian hasil belajar kimia. Grez, et al. (2012:1-2) menemukan bahwa ada kecenderungan self assessment lebih tinggi 


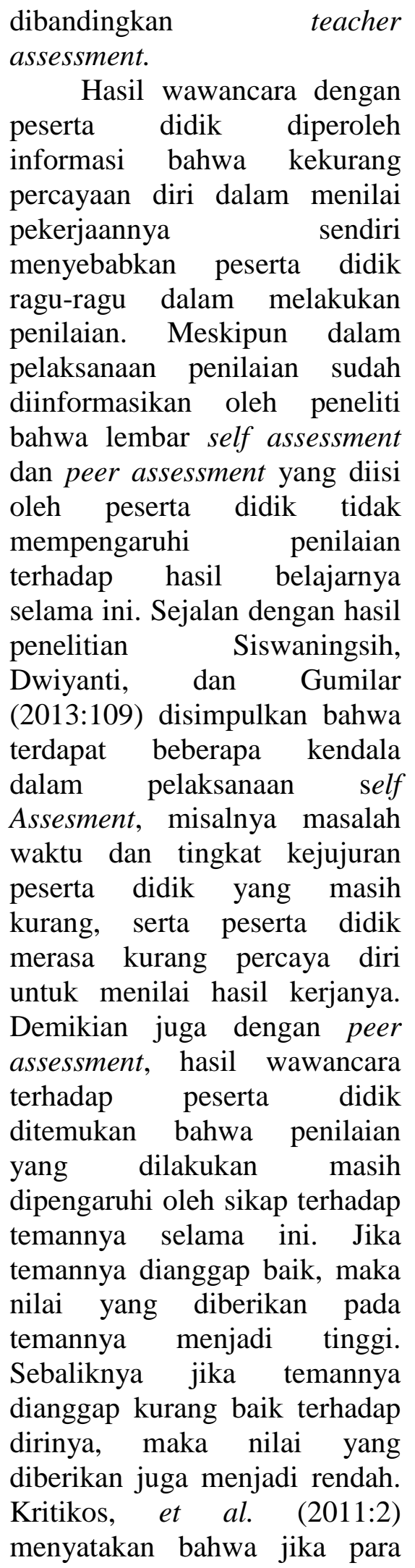

guru akan menerapkan self assessment dan peer assessment, guru perlu memberikan arahan tentang self assessment dan peer assessment sebelum proses asesmen dilaksanakan, karena hal ini dapat meningkatkan kepercayaan diri siswa dalam melakukan penilaian. Teacher assessment dalam penelitian ini sebagai pembanding pada self dan peer assessment digunakan untuk mengecek kejujuran peserta didik dalam melakukan penilaian. Pada Gambar 1 di atas menunjukkan bahwa rerata skor teacher assessment selalu di bawah self dan peer assessment. Hal ini berarti sikap kejujuran siswa masih kurang. Teknik self dan peer assessment sangat diperlukan kejujuran dari siswa. Keuntungan dari penggunaan penilaian self assessment dan peer assessment di kelas antara lain dapat menumbuhkan rasa percaya diri siswa, karena mereka diberi kepercayaan untuk mengevaluasi dan menilai dirinya sendiri dan rekannya. Self dan peer assessment membiasakan, dan melatih peserta didik untuk berbuat jujur, karena mereka dituntut untuk objektif dalam melakukan penilaian.Untuk mengantisipasi ini, dilakukan simulasi penilaian sebelum pelaksanaan penelitian. Siswa berlatih melakukan penilaian dengan teknik self dan peer assessment. 
Penggunaan self dan peer assessment dalam pembelajaran kimia SMA di Pontianak sebaiknya sering dilakukan. Peserta didik perlu dibiasakan untuk melakukan self assessment secara terus menerus dalam proses pembelajaran meskipun sudah dilakukan pelatihan dalam pembelajaran (Shofiyah dan Wasis, 2013:142). Selain itu, self dan peer assessment merupakan teknik penilaian yang paling efektif dalam membentuk karakter siswa (Wijayanti, 2017:14).

\section{b. Penilaian II}

Penilaian kedua melalui teknik self, peer, dan teacher's assessment, secara keseluruhan hasil rerata skor berturut-turut yaitu 2,97 dengan kriteria baik, dan 2,96 dengan kriteria baik. Teache assessment diperoleh rerata skor 2,90 dengan kriteria baik. Perbedaan rerata skor melalui teknik self, peer, dan teacher's assessment secara jelas dapat dilihat pada Gambar 2 ini.

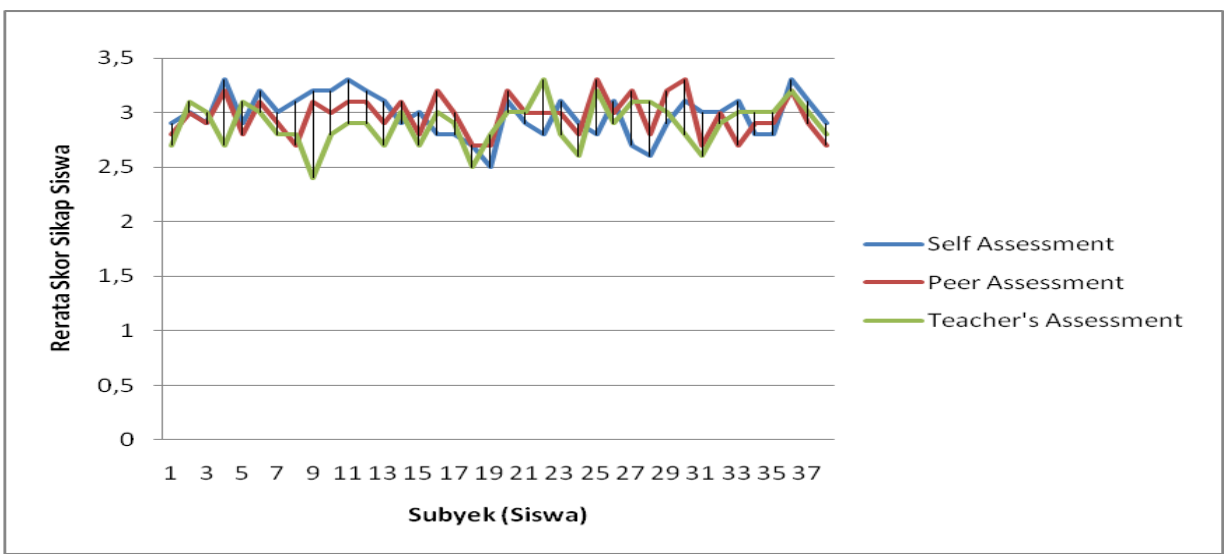

Gambar 2. Rata-rata kemampuan afektif setiap peserta didik melalui self assessment dan peer assessment pada penilaian kedua.

Berdasarkan hasil dari penilaian 2 (kedua) di atas menunjukkan bahwa selisih rerata skor melalui teknik penilaian, self, peer dan teacher assessment pada Gambar 2 semakin kecil. Perolehan rerata skor ketiga penilaian semakin mendekati sama. Hal ini menunjukkan bahwa peserta didik sudah memiliki kepercayaan diri untuk menilai dirinya sendiri dan rekannya, sehingga ketika melakukan penilaian bisa berlaku obyektif atau jujur dalam menilai. Penelitian Siswaningsih, Dwiyanti, dan Gumilar (2013:109) disimpulkan bahwa sikap jujur ini yang merupakan satu diantara kendala dalam pelaksanaan self dan peer assessment. Kendala kejujuran peserta didik dalam pelaksanaan self dan peer assessment dapat diminimalisir dengan seringnya peserta didik menilai dirinya 
sendiri atau menilai temannya dan pengertian jujur dalam kehidupan dijelaskan terlebih dahulu pada peserta didik sebelum menggunakan teknik self assessment (Muslich, 2014:146). Hasil perolehan rerata ketiga skor, yaitu self, peer dan teacher assessment yang mendekati sama maka menunjukkan bahwa sikap kejujuran peserta didik semakin meningkat. Dengan demikian teknik self dan peer assessment efektif digunakan untuk menilai sikap peserta didik dalam pembelajaran kimia.

2. Respon Siswa dan Guru

Hasil analisis angket respon secara keseluruhan yang diberikan pada siswa menunjukkan sebanyak $80,50 \%$ siswa menyatakan setuju dan berdasarkan interpretasi skor angket tergolong tinggi. Hal ini berarti siswa menyetujui penggunaan teknik self dan peer assessment dalam penilaian. Sejalan dengan hasil penelitian Siswaningsih, Dwiyanti, dan Gumilar (2013:115) disimpulkan bahwa sebanyak 94,74\% siswa menyetujui pelaksanaan self dan peer assessment. Siswa menyetujui penggunaan self dan peer assessment karena penilaian ini memberikan pengalaman yang baru pada siswa, sehingga persentase rasa ingin tahu dan antusias terhadap penggunaan self dan peer assessment tergolong tinggi.

Self assessment dan peer assessment memberikan pengaruh terhadap sikap percaya diri siswa. Terbukti dari hasil angket respon menunjukkan bahwa siswa merasa percaya diri untuk mengungkapkan secara lisan hal-hal yang menjadi kelemahannya dalam mempelajari suatu materi pelajaran. Sebelumnya siswa merasa malu untuk mengatakan kekurangannya. Hal ini sejalan dengan pendapat Walser (2009:301) bahwa salah satu tujuan self assessment adalah membantu siswa menggambarkan penampilannya dalam kelas. Rasa percaya diri yang tinggi dalam belajar dapat meningkatkan keberhasilan siswa dalam belajar. Siswa yang memiliki sikap percaya diri yang tinggi akan mampu untuk mencapai berbagai tujuan di dalam hidupnya (Hairida, 2017:53). Dengan demikian self dan peer assessment dapat meningkatkan hasil belajar siswa.

Hasil angket respon pada siswa yang menggunakan self dan peer assessment juga menunjukkan bahwa kedua penilaian ini tidak sulit untuk diimplementasikan dalam pembelajaran. Melalui self dan peer assessment ini diharapkan dapat memberikan manfaat pada siswa SMA di kota Pontianak untuk memperbaiki pembelajaran selanjutnya, sehingga hasil belajarnya menjadi baik. Hasil analisis angket respon guru menunjukkan sebanyak $82,4 \%$ guru menyatakan setuju dan berdasarkan interpretasi skor angket tergolong tinggi. Hal ini sejalan dengan penelitian Shofiyah dan Wasis (2013:142) disimpulkan bahwa respon siswa kelas $\mathrm{X}$ SMAN 1 Sidayu terhadap self assessment yang diterapkan pada kegiatan praktikum sangat baik. 
Respon guru yang tergolong tinggi persetujuannya menunjukkan bahwa penggunaan self dan peer assessment dalam penilaian sangat disetujui guru.

Guru menyetujui penerapan self assessment dan peer assessment dalam pembelajaran, bukan berarti para guru senang menyusun instrumen tersebut. Guru beranggapan self assessment dan peer assement menambah beban bagi guru, karena mereka harus membuat instrumen penilaian sikap lagi, sedangkan lembar observasi yang digunakan untuk menilai sikap selama ini belum dikembangkan sendiri. Hal ini terjadi karena kurangnya pemahaman dan keterampilan guru terhadap prinsip dan jenis penilaian menurut kurikulum 2013, dan pola pembelajaran yang dilaksanakan guru belum berpusat pada peserta didik secara utuh.

\section{SIMPULAN DAN SARAN}

Berdasarkan temuan dan
pembahasan mengenai self assessment dan peer assessment untuk siswa dalam pembelajaran kimia, maka diperoleh kesimpulan, yaitu: 1) Teknik self dan peer assessment efektif digunakan untuk melakukan penilaian sikap siswa, 2) Respon guru terhadap self assessment dan peer assessment menunjukkan rata-rata sebesar 82,4 dengan kriteria baik, dan 3) Respon siswa terhadap penggunaan self assessment dan peer assessment dalam pembelajaran kimia menunjukkan rata-rata sebesar 80,5 dengan kriteria baik.

\section{DAFTAR PUSTAKA}

Alias, M., Masek, A., dan Salleh, H. H. M. 2015. Self, Peer, and Teacher Assessments in Problem Based Learning: Are They in Agreements? ProcediaSocial and Behavioral Sciences. 204: $309-317$.

Amo, E., dan Jareño, F. 2011. Self, Peer and Teacher Assessment as Active Learning Methods. Research Journal of International Studies. 18: 4147.

Chang, C. C., dan Wu, B. H. 2012. Is teacher assessment reliable or valid for high school students under a web-based portfolio environment? Educational Technology \& Society. 15 (4): 265-278.

Grez, L.D., Valcke, M., dan Roozen, I. 2012. How effective are selfand peer assessment of oral presentation skills compared with teachers' assessment?. Active Learning and Higher Education. 13(2): 129-142.

Hairida. 2016. The Effectiveness Using Inquiry Based Natural Science Module with Authentic Assessment to Improve the Critical Thinking and Inquiry Skills of Junior High School Student. Jurnal Pendidikan IPA Indonesia. 5 (2): 209-215.

Hairida, 2017. Pengembangan Instrumen untuk Mengukur Self Efficacy Siswa dalam Pembelajaran Kimia. EDUSAINS. 9 (1): 53-59. 
Hairida. 2017. Keterampilan Calon Guru Kimia dalam Mengembangkan Alternative Assessment. Jurnal Pengajaran MIPA UPI. 22(1): 1 - 7.

Juanda, A. 2017. Optimalisasi Diskusi Kelas Melalui Peer Assessment dan Self assessment untuk Manilai Kemampuan Komunuikasi Lisan Mahasiswa Calon Guru Biologi. Jurnal Pendidikan Matematika dan IPA. 8(2): 1 - 9 .

Kritikos, V.S., Woulfe, J., Sukkar, M.B., dan Saini, B. 2011. Intergroup: Peer Assessment In Problem-Based Learning Tutorials For Undergraduate Pharmacy Students. American Journal of Pharmaceutical Education,75(4): 1-12.

MacMillan, J.H. dan Hearn, J. 2008. "Student Self-Assessment: The Key to Stronger Student Motivation and Higher Achievement". Educational Horizons. 87(1): 40-49.

Muslich, M. 2014. Pengembangan Model Assessment Afektif Berbasis Self Assessment dan Peer Assessment. Jurnal Kebijakan dan Pengembangan Pendidikan. 2(2): 143-148.

Nurmasyitah, N. dan Hudiyatman. 2016. Kendala Guru Dalam Merumuskan Instrumen Penilaian pada Pembelajaran IPS sesuai dengan Ranah Afektif di Gugus I SD Negeri Uteun Pulo Seunagan Timur Nagan Raya. Jurnal Pesona Dasar. 4(2): 48-62.
Purmanah, N.I., Nuryana, dan Puspitasari, E. 2017. Penerapan Self Assessment untuk Menumbuhkan Kesadaran Siswa Tentang Makna Belajar pada Mata Pelajaran IPS di MTs Sabilul Chalim Kecamatan Leuwimunding Kabupataen Majalengka. Jurnal Edueksos. 6(1): 65-80.

Riduwan. 2013. Pengantar Statistika Sosial. Bandung: Alfabeta.

Shofiyah, H. dan Wasis. 2013. Penerapan Self Assessmentpada Kegiatan Praktikum untuk Meningkatkan Hasil Belajar Siswa Kelas X SMAN 1 Sidayu. Jurnal Inovasi Pendidikan Fisika. 2(3): 139142.

Siswaningsih, W., Dwiyanti, G., dan Gumilar, C. 2013. Penerapan Peer Assessment dan Self Assessment pada Tes Formatif Hidrokarbon untuk Feedback Siswa SMA Kelas X. Jurnal Pengajaran MIPA . 18(1): 107115.

Wahyuni, S dan Ibrahim, S. 2012. Asesmen pembelajaran bahasa. Bandung: Refika Aditama.

Walser, T. M. 2009. An action research study of student selfassessment in higher education. Innovation of Higher Education. 34: 299-306.

Widyoko, E.P. 2012. Teknik Penyusunan Instrumen Penelitian. Yogyakarta: Pustaka Belajar. 
48 Jurnal Pendidikan Matematika dan IPA Vol. 9 No. 2 Juli 2018: 37-48

Willey, K. dan Gardner, A.P. 2007. Investigating The Capacity of Self-Assessment and Peer assessment to engage Student and Increase Their Desire to Learn. Makalah Seminar.
Wijayanti, A. 2017. Efektivitas Self Assessment dan Peer Assessment dalam Pembentukan Karakter Siswa. Realita. 15(2): 1-14. 